\title{
Multilevel Water Governance and Problems of Scale: Setting the Stage for a Broader Debate
}

\author{
Timothy Moss $\cdot$ Jens Newig
}

Published online: 18 July 2010

(C) Springer Science+Business Media, LLC 2010

\begin{abstract}
Environmental governance and management are facing a multiplicity of challenges related to spatial scales and multiple levels of governance. Water management is a field particularly sensitive to issues of scale because the hydrological system with its different scalar levels from small catchments to large river basins plays such a prominent role. It thus exemplifies fundamental issues and dilemmas of scale in modern environmental management and governance. In this introductory article to an Environmental Management special feature on "Multilevel Water Governance: Coping with Problems of Scale," we delineate our understanding of problems of scale and the dimensions of scalar politics that are central to water resource management. We provide an overview of the contributions to this special feature, concluding with a discussion of how scalar research can usefully challenge conventional wisdom on water resource management. We hope that this discussion of water governance stimulates a broader debate and inquiry relating to the scalar dimensions of environmental governance and management in general.
\end{abstract}

Keywords Water management - Multilevel governance · Problems of scale $\cdot$ Rescaling

T. Moss

Leibniz Institute for Regional Development and Structural Planning (IRS), 15537 Erkner, Germany

J. Newig $(\bowtie)$

Institute of Environmental and Sustainability Communication, Leuphana University Lüneburg, Scharnhorststr. 1,

21335 Lüneburg, Germany

e-mail: newig@uni.leuphana.de

\section{Scale Matters}

Environmental governance and management are facing a multiplicity of challenges related to spatial scales and multiple levels of governance. Levels of government and administration typically do not fit the environmentally relevant scales, resulting in inefficiencies, spatial externalities, and spillovers. Tension exists also between the traditional nested hierarchies of national politicaladministrative systems and trends toward both the upscaling of governance in the form of multinational agreements or the growing influence of the European Union and downscaling in the form of decentralization of environmental decision-making involving a diversity of local nonstate actors. Cutting across established systems of multilevel governance, new task-specific governance levels (Hooghe and Marks 2003) are currently being created-for instance, to improve the fit with environmental scales (Young 2002). Such processes of re-scaling create a need for adaptation among the involved regions, while altering power positions and the scope of action for state and nonstate actors (Brenner 2004; Brook 2005; Gibbs and others 2002; Swyngedouw 1997). Thus, the effectiveness and efficiency of environmental governance as affected by scale problems and rescaling processes also raise issues of legitimacy and equity.

The governance of water is as old as human civilization itself. Ancient advanced cultures emerged because they were able to tame floods and manage irrigation through centralized bureaucracies (Wittfogel 1957). Today-in an era in which clean drinking water is called "blue gold"water governance has, more than ever, become a particular challenge that inherently involves multiple levels of action with intricate relations to spatial scale. As water is both a fluid and confined to spatial limits, its biophysical 
properties raise the question of which spatial scales or levels are most appropriate for organizing which dimensions of water management. Whereas climate change and globalization processes (including the trade in so-called "virtual water") call for overarching governance units, new modes of governance such as decentralization, deliberation, or citizen participation demand smaller spatial units of water governance. Amid this, river basin management has long become the dominant paradigm for selecting the relevant water governance scale (Ingram 2008; Moss 2003).

Water governance and water resources management take place on various spatial scales. Not only does water work across multiple spatial scales in its ecological dimensions, from the individual organism to the global climate, but the governance of water is currently undergoing substantive change as competencies and terrains of political intervention simultaneously shift upward toward the national or supranational and downward toward the regional or local scale. Whereas some adaptive management approaches call for local self-management of water resources (Olsson and others 2007; Ostrom 1999), water-related processes such as climate change or "virtual water" transfer transcend territorial boundaries and are perhaps best tackled on a global scale. In between, institutional arrangements span the whole range of regional, national, and supranational levels. For example, the European Union's Water Framework Directive, by institutionalizing river basin management, has strengthened the need for inclusive and deliberative modes of governance suited to horizontal interplay between hydrological and politicaladministrative scales of operation and to vertical interplay within each of these scalar dimensions.

Water governance thus exemplifies fundamental issues and dilemmas of scale to modern environmental management and governance.

This special feature of Environmental Management has three broad aims. First, it assembles contributions demonstrating the state of the art in the debate on scales and multilevel governance relating to water. Taking one common field of investigation-water management-permits useful comparisons among the case studies drawn from three continents. We hope that this discussion of water governance stimulates a broader debate and inquiry relating into the scalar dimensions of environmental governance and management in general.

Second, it seeks to map out the breadth of perspectives from which multilevel governance and scale problems in water management can be addressed. It brings together contributions with diverse, but complementary, conceptual approaches to problems of scale in water management. They shed light on the subject from a policy (Benson and Jordan), an economic (Roggero and Fritsch), a deliberative
(Dore and Lebel), a critical (Thiel), and a subjective-constructivist (Vreugdenhil and others) perspective.

Third, we seek to broaden the debate on scales and multilevel governance by challenging conventional wisdom regarding a number of crucial issues, outlined below.

In the following sections, we delineate our understanding of problems of scale and the dimensions of scalar politics that are central to water resource management. We do so by drawing on the insights from the contributions to this Environmental Management special feature. Looking across the contributions, we conclude by discussing how scalar research can usefully challenge conventional wisdom on water resource management.

\section{Problems of Scale and Dimensions of Scalar Politics in Water Management}

Different scholarly disciplines make different uses of the concept of scale. On the one hand, scale denotes a certain dimension, as in "hydrological scale" or "political scale." On the other hand, the term is used to denote a spatial level such as "local scale" (e.g., Swyngedouw 1997). Some scholars distinguish between scale and level, using the former to denote dimensions and the latter to denote a rung on a scale (e.g., Cash and others 2006; Dore and Lebel, this special feature). Here, we distinguish between the notions of scale and level:

- Scalar dimension as an analytical dimension of a problem under study. Two different types of scalar dimensions are of particular importance, namely the biophysical (e.g., hydrological) and the institutional scalar dimension.

- Scalar level as a particular level on a scalar dimension (e.g., the level of a river reach within a river basin or of a municipality in a political-administrative system).

Environmental problems of scale, then, are those problems that arise due to mismatching spatial relations among biophysical processes, administrative structures, and procedures or individual preference (Gibbs and others 2002; Görg and Rauschmayer 2009; Meadowcroft 2002; Young 2002). These include, among others, the following:

- Problems of misfit between different scalar dimensions (problems of scalar fit)

- Problems to identify the "optimal" scalar level in order to address collective problems (optimal scalar level)

- Issues of interplay between different levels on one scalar dimension (problems of vertical interplay)

- Problems emerging from a reconfiguration of scalar levels (problems of rescaling) 
- Efforts to generalize from insights that are valid on a particular scalar level to other scalar levels (problems of upscaling and downscaling).

Problems of fit, interplay, and scale were introduced in the Science Plan of the Institutional Dimensions of Global Environmental Change (IDGEC 1999) project (Young 2005). According to IDGEC, problems of fit relate to the fit of political-administrative with biophysical systems. In the IDGEC terminology, problems of interplay characterize the interplay of institutions within one societal level as well as between levels (horizontal and vertical interplay). Finally, problems of scale address the question of to what extent knowledge about institutions on one particular societal level can be transferred to others (IDGEC 1999, p. 75). As opposed to this definition, problems of scale are defined here more broadly, drawing on scholars such as Tullock (1975), Gibson and others (2000) or Cash and others (2006). Problems of scale here include, in addition to the issue of cross-scale transferability, also problems of scalar fit and of vertical institutional interplay. We also draw on the work of critical geographers on the politics of scale and processes of rescaling environmental governance (Swyngedouw 2004; Swyngedouw and others 2002).

The scalar organization of natural resources (such as water) that cross territorial boundaries proves to be one of the most intractable, yet most important tasks of environmental governance (Huitema and Bressers 2006; Kaika 2003; Swyngedouw and others 2002). Three scalar dimensions of governance appear to be central to water management.

1. From a political science point of view, problems of scale relate to fundamental questions of democratic legitimacy. The higher the scalar level of collective decisionmaking, the lower the possibilities for participation of the relevant constituency ("input-oriented legitimacy") and thus the more pronounced are potential conflicts. This can threaten the acceptability and implementation of environmental governance. On the other hand, the lower the scalar governance level, the more difficult it becomes to effectively tackle environmental problems - in particular, those that are not of a strictly local nature ("output-oriented legitimacy"). Dahl (1994) has termed these scale-dependent trade-offs a "democratic dilemma between citizen participation and system effectiveness." The existing multitude of vertical and horizontal levels of governance can thus be seen as an attempt to mediate different aspects of inputand output-oriented legitimacy (Benz 2006). Notably, scholars in the field of commons research have argued in favor of highly polycentric and multilevel systems for effective and legitimate environmental governance (Ostrom 1999; Armitage 2008). Yet at the same time, policy implementation research has long pointed to the detrimental effect of nested hierarchies of decision-making for effective policy implementation (Pressman and Wildavsky 1984; Tsebelis 1995).

In this special feature, Benson and Jordan draw on a federalist perspective to discuss trade-offs between democratic legitimacy (in an input-oriented understanding) and effectiveness in terms of environmental quality improvements. Legitimacy from both an input and an output perspective plays an important role in the contribution by Dore and Lebel (this special feature). Based on their comparative analysis of deliberative water governance in the Mekong Region, the authors argue in favor of deliberation as a way to improve legitimacy and to cope with the complexities of water management.

2. Related to the above-mentioned issue of output-oriented legitimacy (effectiveness) is the question how the different problems of scale can be addressed most efficiently. From an economic perspective-in particular, that of environmental federalism-this includes the issue of how tasks, revenues, and expenditures regarding water management can be distributed most appropriately among the different vertical levels of governance (Biehl 1996; Oates 1972). The normative idea is that administrativescale levels can be constructed in a way that can best internalize spatial externalities of environmental issues and minimize costs. Thus, in the case of water, institutional arrangements are sought to attain a "perfect mapping" (Breton 1965) between hydrological and institutional scales. As the rescaling of governance levels entails institutional change, transaction cost economics investigates whether improving cooperative arrangements rather than rescaling organizations could be more efficient (Coase 1960; Williamson 1985, 1991).

In this special feature, both Benson and Jordan, and Roggero and Fritsch address the issue of optimal scaling, albeit from different perspectives. Benson and Jordan analyze the upward and downward scaling of tasks, taking the contrasting cases of bathing water quality policy responses in Australia and the European Union. With regard to the question of which tasks should be "scaled" to which level of jurisdiction, the authors distinguish "pollution spillovers" (physical movement of pollutants across jurisdiction boundaries, as defined earlier) from "competitive spillovers" (where states "compete on environmental matters in order to gain a competitive advantage, providing a rationale for centralization"; Benson and Jordan) and from "preservation spillovers," referring to the use of resources (e.g., natural scenery) by citizens from other jurisdictions. Roggero and Fritsch, from a perspective of transaction cost economics, analyze the rescaling of water governance tasks in the Venice Lagoon, drawing on the concept of multilevel governance of nested hierarchies (type I) and cross-jurisdictional, task-specific (type II) 
governance levels (Hooghe and Marks 2003). The analysis is conducted both from the perspective of rationality of the relevant agencies and from the perspective of collectively rational decisions.

3. The recent work of geographers on the politics of scale and processes of rescaling addresses the social production of scale and its impact on the distribution of power (Herod and Wright 2002; Keil and Mahon 2008; Sheppard and McMaster 2004; Wissen and others 2008). Here the issue is how actors gain (or lose) influence as a result of authority being reconfigured around new spatial levels or by virtue of their own ability to work across different scales or levels. Scale, in this literature, is dynamic. It is understood not as a fixed spatial unit but as a temporary embodiment of spatial relations subject to continuous renegotiation and adaptation. This debate on scale is focused less on the attributes of a scalar configuration itself than on the (often contested) process of its production, termed scaling and rescaling (Schmid 2003). Scale is understood, from this perspective, as a medium, an object, and a product of social conflicts and negotiations (Brenner 2004; Smith 1995; Swyngedouw 1997). It follows that the significance of individual scalar levels only becomes apparent when set in its (dynamic) relation to other scalar levels (Brenner 2001). These aspects of the scaling debate in human geography are particularly pertinent to water governance. In Europe, for instance, the scalar configuration of water regulation is being currently reordered around river basins in accordance with the Water Framework Directive (WFD). This policy intervention involves much more than the replacement of one scalar configuration by another. The WFD has initiated a process of negotiation over the form and means of institutionalizing river basin management that is altering established power geometries, creating winners and losers. The principal beneficiaries appear to be those who are capable of acting across the new, post-WFD scales and levels of water management, increasing their scope for influence by means of novel, multi-scalar strategies.

In this special feature, several articles address scalar politics and processes of rescaling, although primarily not from a critical geography perspective. Thiel's case study of water services in the Algarve, Portugal is about upscaling water management to the national level to meet a predicted water supply crisis in the region. With the help of European funds and regulations (themselves expressions of rescaling), the Portuguese government succeeded in gaining control over regional water management from local authorities - and, interestingly, preempting privatizationin the interest of securing the water needs of expanding tourism and agriculture. Dore and Lebel explore the contestation of scales and levels in their study of water governance in the Mekong Region. This transnational river basin is used to illustrate how different actors privilege particular spatial (and temporal) scales and levels in the arguments they advance and the measures they take. Depending on their particular interests and position in the Mekong basin, the actors prioritize either administrative, hydrological, ecosystem, or economic territories. The article provides interesting evidence of "scale jumping" as an effective means of actors to advance their own interests. Vreugdenhil and others build their article around the observation that scales of water management are very much the construction of particular disciplinary perspectives. Focusing on river management in The Netherlands and, in particular, interventions to rejuvenate floodplains, the authors map diverse preferences for dealing with both biophysical and institutional scales in order to identify mismatches in scalar perspectives as they emerge in water management practices.

\section{Challenging Conventional Wisdom: Toward a Broader Research Agenda}

If the contributions to this special feature demonstrate one thing, it is that scale matters in water management. Choices of which collective decisions are to be made on which scalar level of governance-in relation to other levels as well as hydrological scales-deeply affect democratic legitimacy (Dore and Lebel; Benson and Jordan), (cost-) efficiency (Roggero and Fritsch; Benson and Jordan), and equity in terms of power relations through the social construction of scales (Vreugdenhil and others; Thiel; Dore and Lebel).

Water management is a field particularly sensitive to issues of scale because the biophysical/hydrological scale with its different scalar levels from small catchments to large river basins plays such a prominent role. Yet many of the scalar issues touched here are of equal importance to environmental management in general. Air pollution control, ecosystem management, biodiversity governance, contaminated sites - they all refer to more or less characteristic biophysical scales that produce spillovers (Young and others 2006), and all are potentially subject to socially constructed and contested scaling and rescaling of the units of governance.

The articles of this special feature do more, however, than underline the importance of scale. In their detailed, nuanced analyses of scale and scalar politics they challenge elements of conventional wisdom on water resource management.

First, several of the contributions query the effectiveness and legitimacy of the dominant paradigm of water management around the globe today: river basin management. The original idea behind river basin management—namely 
to internalize spillovers within a single hydrological unitis challenged on the basis of empirical evidence presented here (see also Ingram 2008). Several of the authors make the case for more differentiated analyses and assessments. Benson and Jordan (this special feature) question whether the claimed spillovers used to justify the supranational approach by the European Union are actually important enough to legitimize this. Comparison with the Australian model of decentralization shows that biophysical and societal context matters hugely in choosing the "optimal" task scale. Roggero and Fritsch (this special feature) deduce from their comparison of task-specific governance scales (such as the basin scale) with multilevel governance on territorial scales that it is by no means clear that water management on the hydrological scale is in every respect "optimal."

Second, fresh light is also shed on that other paradigm of modern water management: participatory governance. Dore and Lebel (this special feature) find that whereas deliberative and participatory processes have great potential to integrate governance within and across scales, the power positions of actors to (re-)construct scales clearly influence the success of participation (see also Newig and Fritsch 2009). Similarly, the contributions by Vreugdenhil and others, Thiel, and Dore and Lebel demonstrate the social construction of scales and rescaling processes and the role of powerful actors in this process, thus questioning the static assumptions regarding the possibility of finding "optimal" "scales inherent to economic and many political science approaches. The normative claims for new forms of "good governance" and decentralization are also questioned by the evidence put forward by Thiel (this special feature), who highlights the importance of power play in rescaling water management with the example of the Portuguese government creating a "hydraulic state" (Wittfogel 1957) in the Algarve.

With these critical arguments and challenging findings, the scale perspective put forward in this special feature's contributions is intended to provide insight and stimulation both for scholarly debate and for environmental managers in the field. By shedding new light on scalar and multilevel aspects of environmental governance, we hope to broaden the debate on the democratic legitimacy, efficiency, and equity of water management and environmental governance in general.

Acknowledgements This special feature of Environmental Management arose from a session on "Multilevel Water Governance: Coping with Problems of Scale" within CAIWA 2007-International Conference on Adaptive \& Integrated Water Management, Coping with Complexity and Uncertainty, Basel, 12-15 November 2007. Parts of this research have been conducted within the DFG-funded project cluster "Scalar problems of environmental governance-the example of the institutionalization of river basin management through the EC Water Framework Directive" (PAK 463, 2010-2013). We are indebted to Ines Dombrowsky and Markus Wissen for discussions and contributions relating to the economics and dynamics of scale. We thank all contributors for their productive collaboration on this special feature, Virginia H. Dale and Linda O'Hara for their support in completing this feature, and two anonymous reviewers who helped improve this manuscript.

\section{References}

Armitage D (2008) Governance and the commons in a multi-level world. International Journal of the Commons 2(1):7-32

Benz A (2006) Governance in Mehrebenensystemen. In: Schuppert GF (ed) Governance-Forschung. Vergewisserung über Stand und Entwicklungslinien. 2. Auflage. Nomos, Baden-Baden, pp 95-120

Biehl D (1996) Zur ökonomischen Theorie des Föderalismus: Grundelemente und ihre Anwendung auf die EU-Finanzunion. In: Schneider H, Wessels W (eds) Föderale Union, Europas Zukunft? Analysen-Kontroversen-Perspektiven. C.H. Beck, München, pp 99-122

Brenner N (2001) The limits to scale? Methodological reflections on scalar structuration. Progress in Human Geography 24(4):591614

Brenner N (2004) New state spaces: urban governance and the rescaling of statehood. Oxford University Press, Oxford

Breton A (1965) A theory of government grants. Canadian Journal of Economics and Political Science 31(2):175-187

Brook MM (2005) Re-scaling the Coomons: Miskitu Indians, forest communities and transnational development networks. PhD thesis, University of Texas at Austin. http://www.library.utexas. edu/etd/d/2005/brookm74928/brookm74928.pdf

Cash DW, Adger WN, Berkes F, Garden P, Lebel L, Olsson P, Pritchard L, Young O (2006) Scale and cross-scale dynamics: governance and information in a multilevel world. Ecology and Society 11(2):8

Coase RH (1960) The problem of social cost. Journal of Law and Economics 3:1-44

Dahl RA (1994) A democratic dilemma: system effectiveness versus citizen participation. Political Science Quarterly 109(1):23-34

Gibbs D, Jonas A, While A (2002) Changing governance structures and the environment: economy-environment relations at local and regional scales. Journal of Environmental Policy \& Planning 4:123-138

Gibson CC, Ostrom E, Ahn T-K (2000) The concept of scale and the human dimensions of global change: a survey. Ecological Economics 32:217-239

Görg C, Rauschmayer F (2009) Multi-level-governance and the politics of scale. The challenge of the Millennium Ecosystem Assessment. In: Kütting G, Lipschutz RD (eds) Environmental governance. Power and knowledge in a local-global world. Routledge, London, pp 81-99

Herod A, Wright M (eds) (2002) Geographies of power: placing scale. Oxford University Press, Oxford

Hooghe L, Marks G (2003) Unraveling the central state, but how? Types of multi-level governance. American Political Science Review 97(2):233-243

Huitema D, Bressers JThA (2006) Scaling water governance: the case of the implementation of the European Water Framework Directive in the Netherlands. Paper presented to the synthesis conference of the Institutional Dimensions of Global Environmental Change Program, Bali, Indonesia, December 2006. CSTM-reeks No. 304, pp 1-22. http://www2.bren.ucsb.edu/ $\sim$ idgec/papers/David_Huitema.pdf 
IDGEC (1999) Institutional dimensions of global environmental change. Science plan. IHDP Report No. 9. IHDP, Bonn

Ingram H (2008) Beyond universal remedies for good water governance: a political and contextual approach. Paper presented at the Rosenberg forum for water policy, Zaragoza, Spain, June 25-26. http://rosenberg.ucanr.org/documents/V\%20Ingram.pdf

Kaika M (2003) The Water Framework Directive: a new directive for a changing social, political and economic European framework. European Planning Studies 11(3):299-316

Keil R, Mahon R (eds) (2008) Leviathan undone? The political economy of scale. University of British Columbia Press, Vancouver

Meadowcroft J (2002) Politics and scale: some implications for environmental governance. Landscape and Urban Planning 61:169-179

Moss T (2003) Solving problems of 'fit' at the expense of problems of 'interplay'? The spatial reorganisation of water management following the EU Water Framework Directive. In: Breit $\mathrm{H}$, Engels A, Moss T, Troja M (eds) How institutions change. Perspectives on social learning in global and local environmental contexts. Leske+Budrich, Opladen, pp 85-121

Newig J, Fritsch O (2009) Environmental governance: participatory, multilevel-and effective? Environmental Policy and Governance 19(3):197-214

Oates WE (1972) An essay on fiscal federalism. Journal of Economic Literature 37:1120-1149

Olsson P, Folke C, Galaz V, Hahn T, Schultz L (2007) Enhancing the fit through adaptive co-management: creating and maintaining bridging functions for matching scales in the Kristianstads Vattenrike Biosphere Reserve, Sweden. Ecology and Society 12(1):28

Ostrom E (1999) Coping with tragedies of the commons. Annual Review of Political Science 2:493-535

Pressman JL, Wildavsky A (1984) Implementation: how great expectations in Washington are dashed in Oakland. University of California Press, Berkeley

Schmid C (2003) Raum und Regulation. Henri Lefebvre und der Regulationsansatz. In: Brand U, Raza W (eds) Fit für den Postfordismus? Theoretisch-politische Perspektiven des Regulationsansatzes. Westfälisches Dampfboot, Münster, pp 217242

Sheppard E, McMaster RB (eds) (2004) Scale and geographic inquiry. Nature, society, and method. Oxford University Press, Oxford
Smith N (1995) Remaking scale: competition and cooperation in prenational and postnational Europe. In: Eskelinen H, Snickars F (eds) Competitive European peripheries. Springer, Berlin, pp 59-74

Swyngedouw E (1997) Neither global nor local. "Glocalization" and the politics of scale. In: Cox K (ed) Spaces of globalization. Reasserting the power of the local. Guilford, New York, pp 137-166

Swyngedouw E (2004) Scaled geographies. Nature, place, and the politics of scale. In: McMaster R, Sheppard E (eds) Scale and geographic inquiry: nature, society and method. Blackwell, Oxford, pp 129-153

Swyngedouw E, Page B, Kaika M (2002) Sustainability and policy innovation in a multilevel context: crosscutting issues in the water sector. In: Getmis P, Heinelt H, Kafkalas G, Smith R, Swyngedouw E (eds) Participatory governance in multi-level context: concepts and experience. Leske+Budrich, Opladen, pp 107-131

Tsebelis G (1995) Decision making in political systems: veto players in presidentialism, parliamentarism, multicameralism and multipartism. British Journal of Political Science 25(3):289-325

Tullock G (1975) Federalism: problems of scale. Public Choice 6:19-29

Williamson OE (1985) The economic institutions of capitalism. Free Press, New York

Williamson OE (1991) Comparative economic organization: the analysis of discrete structural alternatives. Administrative Science Quarterly 36(2):269-296

Wissen M, Röttger B, Heeg S (eds) (2008) Politics of scale. Räume der Globalisierung und Perspektiven emanzipatorischer Politik. Westfälisches Dampfboot, Münster

Wittfogel KA (1957) Oriental despotism: a comparative study of total power. Yale University Press, New Haven

Young OR (2002) The institutional dimensions of environmental change: fit, interplay, and scale (global environmental accords: strategies for sustainability). MIT Press, Cumberland

Young OR (2005) Science plan. Institutional dimensions of global environmental change. International Human Dimensions Programme on Global Environmental Change (IHDP), Bonn

Young OR, Berkhout F, Gallopin GC, Janssen MA, Ostrom E, van der Leeuw S (2006) The globalization of socio-ecological systems: an agenda for scientific research. Global Environmental Change 16:304-316 